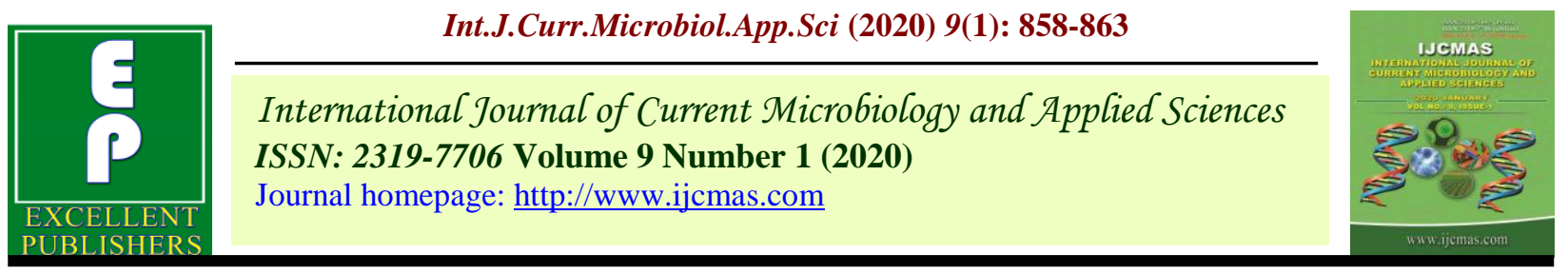

Original Research Article https://doi.org/10.20546/ijcmas.2020.901.095

\title{
Influence of Sulphur Application on the Yield of Gobhi Sarson (Brassica napus L.)
}

\author{
Seema Sharma $^{1^{*}}$ and Sumesh Chopra ${ }^{2}$ \\ ${ }^{1}$ Krishi Vigyan Kendra, Pathankot, India \\ ${ }^{2}$ FASC, Gurdaspur, India \\ *Corresponding author
}

\begin{tabular}{|l|}
\hline Ke y w o r d s \\
Mustard, Gypsum, \\
Yield, Yield \\
attributes, Siliquae
\end{tabular}

\section{A B S T R A C T}

A field experiment was conducted at farmers field during rabi season in the year 2014-15 and 2015-16 to study the influence of sulphur application on seed yield of mustard. Six levels of sulphur were applied to supply $\left(15 \mathrm{~kg} \mathrm{~S} \mathrm{ha}^{-1}, 20 \mathrm{~kg} \mathrm{Sha}^{-1}\right.$, $25 \mathrm{~kg} \mathrm{~S} \mathrm{ha}^{-1}, 30 \mathrm{~kg} \mathrm{~S} \mathrm{ha}^{-1}, 35 \mathrm{~kg} \mathrm{~S} \mathrm{ha}^{-1}$ and $40 \mathrm{~kg} \mathrm{~S} \mathrm{ha}^{-1}$ ). Results of the experiment revealed that yield attributes like plant height, number of primary and secondary branches per plant, number of siliquae per plant,number of seeds per siliqua,and1000 seed weight were maximum in T4 treatment where $25 \mathrm{~kg} \mathrm{~S} \mathrm{ha}^{-1}$ was applied and minimum in T1 treatment (control). However, there was no significant influence of treatments on plant height, number of primary branches and secondary per plant. Seed and stover yield of mustard was significantly influenced with sulphur application. The seed and stover yield increased progressively and significantly with each successive doses of sulphur application but maximum seed yield was observed in T4 treatment where $25 \mathrm{~kg} \mathrm{~S}$ ha- ${ }^{1}$ was applied.

\section{Introduction}

Oilseeds have an important place in Indian agriculture next to cereals. Oilseed crops form the second major group among agricultural crops after cereals in the country. Mustard seed has high nutritive value with protein content of $28-36 \%$. Mustard a winter (rabi) season crop that requires relatively cool temperature, a fair supply of soil moisture during the growing season and a dry harvest period (Banerjee et al., 2010). In India, total area under mustard crop is 6652 thousand ha with production 7109 thousand tonnes (Anonymous, 2016-17) but the average yield of rapeseed-mustard in India is only 1145 $\mathrm{kgha}^{-1}$ (Economic survey, 2013) due to the lack of optimum use of nutrients particularly sulphur which is one of the important factors responsible for its low yield. Application of sulphur was reported to increase yield attributes and yield of Indian mustard (Patel et 
al., 2009, Kumar et al., 2011), which also has a significant effect on oil, fatty acid (Ahmad and Abdin, 2000) and glucosinolates content in mustard seed (Falk et al., 2007). Sulphur is one the fourth major nutrient and plays a major role in providing nutrition to oilseed crops, particularly those belonging to cruciferae family. Sulphur is involved in various metabolic process of the plants and is absolutely necessary for synthesis of essential amino acids like-cysteine and methionine. Sulphur is also involved in the formation of chlorophyll and synthesis of oils, the SHsulphydry linkages provide the source of pungency in oils. It is involved in the formation of glycosides, which on hydrolysis increases the oil content of mustard and improve the quantity and quality of oilseeds. Sulphur application has a marked effect on soil properties and is also used as soil amendment to improve the availability of other nutrients in soil as gypsum and pyrite. Between the two common sources of sulphur, a relatively large deposit of gypsum are available in India and is a cheap source of sulphur, hence could also be better source of sulphur for oilseed crops. Khan and Hussain, (1999) showed the highest seed and oil yield in mustard (Brassica juncea) cv. Kranti, Varuna and Rohini was obtained by applying $20 \mathrm{~kg}$ sulphur per hectare. Sulphur deficiency greatly influences growth and yield of seed crop, which reduces the crop-yield to an extent of 10-30 per cent (Saalbach, 1973).Keeping in view the importance of sulphur nutrition in mustard this study was conducted to evaluate the influence of sulphur application in increasing seed yield of mustard.

\section{Materials and Methods}

The field study was conducted at farmers field during rabi season, in the year 2014-15 and 2015-16, to study the influence of sulphur application on seed yield of mustard. Six levels of sulphur were applied $\left(15 \mathrm{~kg} \mathrm{~S} \mathrm{ha}^{-1}\right.$, $20 \mathrm{~kg} \mathrm{Sha}^{-1}, 25 \mathrm{~kg} \mathrm{~S}^{-1}, 30 \mathrm{~kg} \mathrm{~S}^{-1}, 35 \mathrm{~kg} \mathrm{~S}$ $\mathrm{ha}^{-1}$ and $\left.40 \mathrm{~kg} \mathrm{~S} \mathrm{ha}^{-1}\right)$. Surface soil samples (0$15 \mathrm{~cm})$ collected from the experimental site were analysed for physico-chemical characteristics and results reveal that the soil was sandy loam in texture, neutral in soil reaction ( $\mathrm{pH} 7.1)$, medium in organic carbon $(0.41 \%)$, medium in available phosphorus (21.2 $\left.\mathrm{kgha}^{-1}\right)$, medium in available potassium $\left(112 \mathrm{~kg} \mathrm{ha}^{-1}\right)$ and low in available sulphur (8.5 ppm). Crop was sown in first fortnight of October. Mustard variety GSC-7 was tested for six levels of sulphur. The experiment was laid out in randomized block design. Gypsum as a source of sulphur was applied at the time of sowing as a basal dose. The crop was sown at a row to row distance of $45 \mathrm{~cm}$ using a seed rate $3.0 \mathrm{~kg} \mathrm{ha}{ }^{-1}$. Urea and phosphorus fertilizers were applied as per package and practices of PAU. Interculturing, thinning and weeding were carried out as and when required. Observations on yield attributes and yield of mustard were recorded. Plant height, number of primary and secondary branches per plant was recorded at maturity from five representative plants in each treatment. Number of seeds per siliqua was recorded from average of 25 randomly collected siliquae in each treatment. Seeds were randomly collected from the produce of net plot to determine 1000-seed weight.

\section{Results and Discussion}

\section{Yield attributes}

Plant height is an important morphological character associated with vegetative growth. Plant height is often used to monitor the effect of different treatments on crop growth. Effect of sulphur on plant height of gobhi sarson was studied and it was observed that sulphur application failed to influence the plant height at maturity in both years (Table 1). However maximum plant height was observed in 
T4treatment where $25 \mathrm{~kg} \mathrm{Sha}^{-1}$ was applied. The data indicated that plant height was not significantly affected with different levels of sulphur. Similar results were observed by Sardana and Sheoran (2011), where application of $20 \mathrm{kgS} \mathrm{ha}^{-1}$ did not influence plant height. There was no significant influence of treatments on number of primary branches and secondary per plant. However, maximum number of primary and secondary branches per plant was recorded in T4treatment where $25 \mathrm{~kg} \mathrm{Sha}^{-1}$ was applied and minimum number primary and secondary branches per plant was recorded in $\mathrm{T} 1$ treatment (control) (table 1). Numbers of siliquae per plant which represent the seed bearing capacity are considered the primary determinants of yield in mustard. It is a very important yield contributing character having direct effect on seed yield of the crop. Data regarding number of siliquae per plant are presented in table 1. Data reveals that maximum number of siliquae per plant was recorded in T4 treatment where $25 \mathrm{~kg} \mathrm{Sha}^{-1}$ was applied and minimum number of siliquae per plant was observed in $\mathrm{T} 1$ treatment (control). A significant increase of 3.1, 5.1 per cent in number of siliquae per plant was observed in T4 treatment where $25 \mathrm{~kg} \mathrm{~S}^{-1}$ was applied over treatment $\mathrm{T} 3$ and $\mathrm{T} 2$ treatmentwhere 20 and $15 \mathrm{~kg} \mathrm{~S} \mathrm{ha}{ }^{-1}$ was applied. There is 9.0 per cent increase in number of siliquae per plant in $\mathrm{T} 4$ treatment where $25 \mathrm{~kg} \mathrm{~S} \mathrm{ha}^{-1}$ was applied over $\mathrm{T} 1$ treatment (control). The marked improvement in number of siliquae per plant with the application of sulphur seems to be due to its profound influence in enhancing branching which might have facilitated greater flowers formation, later on adequate supply of metabolites and nutrients matching to the demands of reproductive structures for their growth and development which ultimately led to increase in various yield components and finally seed yield (Sipai et al., 2015). As mustard is a long duration crop, being indeterminate in nature and the favourable effect of sulphur in improving nutritional environment extended over a long duration (Kapur et al., 2010). There was not any significant increase in number of siliquae per plant with further increasing sulphur levels. Number of seeds per siliqua is also a major yield contributing character. The data pertaining to the number of seeds per siliqua reveals that maximum number of seeds per siliqua was observed in treatment $\mathrm{T} 4$ where $25 \mathrm{~kg} \mathrm{~S} \mathrm{ha}{ }^{-1}$ was applied and minimum number of seeds per siliqua was observed in T1 treatment (control). However, a significant increase of $7.2,10.6$ and 15 per cent in number of seeds per siliqua was observed in T4 treatment where $25 \mathrm{~kg} \mathrm{~S}^{-1}$ was applied over T3 (20 kg S ha-1), T2 (15 kg S ha $\left.{ }^{-1}\right)$ and T1 (control) treatments. Treatments T5, T6 and $\mathrm{T} 7$ where 30,35 and $40 \mathrm{~kg} \mathrm{~S} \mathrm{ha}{ }^{-1}$ was applied remained at par with treatment $\mathrm{T} 4$ where $25 \mathrm{~kg} \mathrm{~S} \mathrm{ha}{ }^{-1}$ was applied which indicates that there is no increase in number of seeds per siliqua with further increasing sulphur level. Increase in these parameters could be also ascribed to overall improvement in plant growth and vigour with sulphur fertilization that favoured both the grain formation and grain development (Mehriya and Khangarot, 2000). A part of beneficial effect of sulphur on yield attributes seems to be due to better availability of nutrients and their translocation, which reflects in terms of increased yield attributes of the crop (Khanpara et al., 1993). These results are in accordance with the findings of Tomar et al., (1996). Plant well supplied with sulphur will have relatively larger photosynthesizing area, consequently accumulating higher quantities of photosynthates which will be translocated to sink site that is pods and seeds (Kaur et al., 2019). Maximum 1000- seed weight was observed in T4 treatment where $25 \mathrm{~kg} \mathrm{~S}^{-1}$ was applied. However there was no significant influence of treatments in influencing the 1000- seed weight. 
Table.1 Effect of different levels of sulphur on yield attributes of Gobhi Sarson (B. napus)(mean of two years)

\begin{tabular}{|c|c|c|c|c|c|c|}
\hline Treatments & $\begin{array}{l}\text { Plant } \\
\text { height }\end{array}$ & $\begin{array}{l}\text { Primary } \\
\text { branches } \\
\text { per plant }\end{array}$ & $\begin{array}{c}\text { Secondary } \\
\text { branches } \\
\text { per plant }\end{array}$ & $\begin{array}{c}\text { Number of } \\
\text { silquae per plant }\end{array}$ & $\begin{array}{c}\text { Number of } \\
\text { seeds per } \\
\text { siliqua }\end{array}$ & $\begin{array}{c}1000 \\
\text { seed } \\
\text { weight } \\
\text { (g) }\end{array}$ \\
\hline $\begin{array}{l}\text { Control } \\
\text { (T1) }\end{array}$ & 157 & 4.55 & 5.1 & 244 & 18.0 & 4.6 \\
\hline $\begin{array}{c}\text { 15kg S ha } \\
\text { (T2) }\end{array}$ & 158 & 4.56 & 5.2 & 253 & 18.7 & 4.7 \\
\hline $\begin{array}{c}\text { 20kg S ha } \\
\text { (T3) }\end{array}$ & 159 & 4.59 & 5.3 & 258 & 19.3 & 4.7 \\
\hline $\begin{array}{c}25 \mathrm{~kg} \mathrm{~S} \mathrm{ha-1} \\
\text { (T4) }\end{array}$ & 161 & 4.62 & 5.4 & 266 & 20.7 & 4.8 \\
\hline $\begin{array}{c}\text { 30kg S ha } \\
\text { (T5) }\end{array}$ & 160 & 4.61 & 5.3 & 265 & 19.7 & 4.8 \\
\hline $\begin{array}{c}\text { 35kg S ha } \\
\text { (T6) }\end{array}$ & 160 & 4.61 & 5.3 & 265 & 19.7 & 4.8 \\
\hline $\begin{array}{c}\text { 40kg S ha } \\
\text { (T7) }\end{array}$ & 159 & 4.60 & 5.3 & 265 & 19.7 & 4.8 \\
\hline $\begin{array}{c}\text { CD } \\
(\mathbf{P}=0.05)\end{array}$ & ns & ns & ns & 5.1 & 1.1 & ns \\
\hline
\end{tabular}

Table.2 Effect of different levels of sulphur on yield parameters of Gobhi Sarson (B. napus) (mean of two years)

\begin{tabular}{|c|c|c|c|}
\hline Treatments & $\begin{array}{c}\text { Seed } \\
\text { yield }\left(q h a^{-1}\right)\end{array}$ & Stover yield $\left(\right.$ qha $\left.^{-1}\right)$ & Harvest index (\%) \\
\hline Control (T1) & 17.7 & 70.3 & 20.0 \\
\hline 15kg S ha' (T2) & 19.4 & 73.3 & 20.9 \\
\hline $20 k g \mathrm{~S} \mathrm{ha}^{-1}$ (T3) & 19.8 & 73.7 & 21.1 \\
\hline $25 \mathrm{~kg} \mathrm{~S} \mathrm{ha}^{-1}$ (T4) & 24.3 & 82.8 & 22.6 \\
\hline 30kg S ha ${ }^{-1}$ (T5) & 24.2 & 82.3 & 22.7 \\
\hline 35kg S ha ${ }^{-1}$ (T6) & 24.3 & 82.6 & 22.7 \\
\hline 40kg S ha ${ }^{-1}$ (T7) & 23.9 & 82.4 & 22.5 \\
\hline $\mathrm{CD}(\mathbf{P}=\mathbf{0 . 0 5})$ & 2.2 & 1.3 & 0.81 \\
\hline
\end{tabular}

Yield

The average seed, stover yield and harvest index were influenced significantly due to the application of sulphur (Table 2). The seed yield increased progressively and significantly with each successive doses of sulphur application but maximum seed yield was observed in T4 treatment where $25 \mathrm{~kg} \mathrm{~S}$ $\mathrm{ha}^{-1}$ was applied (Table 2). A significant increase of 37.2 per cent in seed yield was recorded in $\mathrm{T} 4$ treatment where $25 \mathrm{~kg} \mathrm{~S}^{-}{ }^{-}$ 
${ }^{1}$ was applied over T1 treatment (control).Seed yield increased significantly by 25.2 and 22.7 per cent in T4 treatment where $25 \mathrm{~kg} \mathrm{~S}^{-1}$ was applied over T2(15 kg S ha $\left.{ }^{-1}\right)$ and T3(20 $\mathrm{kg} \mathrm{S} \mathrm{ha}{ }^{-1}$ ) treatment. However, with further increasing dose of sulphur there was no significant increase in seed yield and treatment T5, T6, T7 where 30, 35 and 40kg S $\mathrm{ha}^{-1}$ was applied remained at par with $\mathrm{T} 4$ treatment where $25 \mathrm{~kg} \mathrm{~S} \mathrm{ha}{ }^{-1}$ was applied. Stover yield also followed the similar pattern with maximum stover yield in T4 treatment and minimum in $\mathrm{T} 1$ treatment (Table 2). Similar results have been reported by Raj et al., (1998). The increase in seed and stover yield of mustard might be attributed due to essential role of sulphur for plant growth and yield through its effect on biochemical functioning related enzyme activation (Sharma, 1994).

Sulphur nutrition also enhances cell multiplication, elongation, expansion and imparts a deep green colour to leaves due to better chlorophyll synthesis, which in turn increases the effective area for photosynthesis, resulting in relatively greater amount of dry matter accumulation in comparison to sulphur deficient plants (Mehriya and Khangarot, 2000). Seed yield also increased due to enhanced rate of photosynthesis and carbohydrate metabolism as influenced by sulphur application. Sulphur, augmented the translocation of photosynthate to sink site. The results are in close conformity with that of Singh and Meena (2004), Rajput et al., (1993).

On the basis of aforesaid findings, it could be concluded that sulphur applied @25 kg ha ${ }^{-1}$ resulted in maximum increase in mustard yield in sulphur deficient soils.

\section{References}

Ahmad, A., and Abdin, M.Z. 2000. Effect of sulphur application on lipid, RNA and fatty acid content in developing seeds of rapeseed (Brassica campestris L.). Plant Science. 150: 71-76.

Anonymous 2016-2017. https:// Knoema.com/ESIAPYMC 2017/ economic survey 2016-2017-India-areaproduction and yield of major crops.

Banerjee, A., Datta, J . K ., Mondal, N. K . 2010. Impact of different combined doses of fertilizers with plant growth regulators on growth, yield attributes and yield of mustard (Brassica campestris cv. B9) under old alluvial soil of Burdwan, West Bengal. Front Agric China 4: 341-351.

Economic survey. 2013. Statistical Appendix. Ministry of Home Affairs. Government of India, A17-A19. Available at http://indianbudget.nic.in

Falk, K.L., Tokuhisa, J.G., Gershenzon, J. 2007. The effect of sulfur nutrition on plant glucosinolate content: Physiology and molecular mechanisms. Plant Biology. 9: 573-581.

Kapur, L.T., Patel, A.R., Thakor, R.F. 2010. Yield attributes and yield of mustard (Brassica juncea L. Czern and Coss) as affected by sulphur levels. An Asian Journal of Soil Science. 5 (1): 216-217.

Kaur, M., Kumar, S., Kaur, A. 2019. Effect of foliar application of nitrogen, phosphorus and sulphur on growth and yield of Gobhi Sarson (Brassica napus L.) in central Punjab. Journal of Oilseed Brassica. 10(1): 47-50.

Khan, N., and Husain, K. 1999.Performance of mustard varieties in relation to doses of sulphur. Advances in Plant Science. 12. (I):115-118.

Khanpara, V.D., Porwal, B.L., Sahu, M.P., Patel, J.C. 1993. Effect of nitrogen and sulphur on growth and yield of mustard (Brassica juncea) on vertisol. Indian Journal of Agronomy. 38 (2): 266-269.

Kumar, S., Verma S.K., Singh T.K., Singh S. 
2011.Effect of nitrogen and sulphur on growth, yield and nutrient uptake by Indian mustard (Brassica juncea). Indian Journal of Agricultural Sciences. 81: 145-149.

Mehriya, M.L. and Khangarot, S.S. 2000. Response of mustard (Brassica juncea L. Czern and Coss) to sulphur and growth regulators. Annals of Arid zone 39 (1): 81-82.

Patel, G.M., Patel B.T., Dodia I.N., Bhatt V.K., Bhatt R.K. 2009. Effect of sources and levels of sulphur on yield, quality and nutrient uptake of mustard (Brassica juncea L.) varieties in loamy sand soil. Journal of Soils and Crops. 19: 30-35.

Raj, M., Saich, S.N., Mehta, S.C. 1998. Growth and yield of mustard as affected by sources and time of sulphur applications under dry land conditions. Annals of Agri Bio Research. 3(1): $67-$ 70.

Rajput, R.L., Yadav, R.P., Verma, O.P. 1993. Effect of sulphur and sources on mustard (Brassica juncea) production. Bhartiya Krishi Anusandhan Partrika. 8(3-4):185186.

Saalbach, E. 1973.The effect of sulphur, magnesium and sodium on yield and quality of agricultural crops. Pontificiae Acad. Sci. ScriptaVaria Nr.38: 541-589. Sardana,V. and Sheroan, P. 2011. Production potential of canola oilseed rape (Brassica napus) cultivars in response to nitrogen and sulphur nutrition.

Sharma, J.P. 1994. Response of Indian mustard (Brassica juncea L.) to different irrigation schedules, nitrogen and sulphur levels. Indian Journal of Agronomy. 39(3): 421-425.

Singh, A., Meena N.L. 2004. Effect of nitrogen and sulphur on growth, yield attributes and seed of mustard (Brassica juncea L.) in eastern plains of Rajasthan. Indian Journal of Agronomy. 49(3): 186-188.

Sipai, A.H., Patel, J.J., Patel, N.I. 2015. Effect of sulphur and zinc with and without FYM on yield and yield attributes of mustard [Brassica juncea (L.) Czern and Coss] grown on light textured soil of Kachchh. An Asian Journal of Soil Science. 10 (2): 191-200.

Tomar, S., Tomar, T.S., Kumar, S., Tomar, S., Singh, M. and Singh, D. (1996). Response of Indian mustard (Brassica juncea L.) varieties to $\mathrm{N}, \mathrm{P}$ and $\mathrm{K}$ fertilizers. Indian Journal of Agronomy., 41(4): 624-625.

\section{How to cite this article:}

Seema Sharma and Sumesh Chopra. 2020. Influence of Sulphur Application on the Yield of Gobhi Sarson (Brassica napus L.). Int.J.Curr.Microbiol.App.Sci. 9(01): 858-863. doi: https://doi.org/10.20546/ijcmas.2020.901.095 